\title{
Significant Mitigation Measures for Critical Factors of Cost Overrun in Highway Projects of Pakistan
}

\author{
Samiullah Sohu \\ Faculty of Civil and Environmental \\ Engineering \\ Universiti Tun Hussein Onn Malaysia \\ Parit Raja, Johor, Malaysia \\ sohoosamiullah@gmail.com
}

Ashfaque Ahmed Jhatial

Faculty of Civil and Environmental Engineering

Universiti Tun Hussein Onn Malaysia

Parit Raja, Johor, Malaysia.

aajhatial@hotmail.com

\author{
Abd Halid Abdullah \\ Faculty of Civil and Environmental \\ Engineering \\ Universiti Tun Hussein Onn Malaysia \\ Parit Raja, Johor, Malaysia \\ abdhalid@uthm.edu.my \\ Kaleem Ullah \\ Faculty of Civil and Environmental \\ Engineering \\ Universiti Tun Hussein Onn Malaysia \\ Parit Raja, Johor, Malaysia \\ gf150051@siswa.uthm.edu.my
}

\author{
Sasitharan Nagapan \\ Faculty of Civil and Environmental \\ Engineering \\ Universiti Tun Hussein Onn Malaysia \\ Parit Raja, Johor, Malaysia \\ sasitharan@uthm.edu.my \\ Imtiaz Ali Bhatti \\ Faculty of Civil and Environmental \\ Engineering \\ Universiti Tun Hussein Onn Malaysia \\ Parit Raja, Johor, Malaysia \\ gf170069@siswa.uthm.edu.my
}

\begin{abstract}
Stakeholders of the construction industry and academia are often facing problems of cost overrun. It has been observed that many constructions of highway projects are not completed at the approved cost due to certain factors. The objective of this research is to identify the cost overrun critical factors involved in highway projects with their significant mitigation measures. In this regard, literature review helped to identify 64 factors of cost overrun. Based on these 64 common factors, a preliminary survey was carried out among 30 selected respondents of highway projects to identify the critical factors of cost overrun and its possible mitigation measures. Results of the preliminary study reported 8 critical factors and 42 possible mitigation measures for the identified factors. Another questionnaire was established on the findings of the preliminary survey and was distributed among 350 stakeholders of highway projects to identify the significant mitigation measures of finding critical factors of cost overrun. In total, 8 significant mitigation measures were identified as causative and critical factors of cost overrun. The findings of this research would be helpful for the construction practitioners who are dealing with cost overrun issues in the highway projects of Pakistan.
\end{abstract}

Keywords-mitigation measures; critical factors; cost overrun; highway projects; Pakistan

\section{INTRODUCTION}

A project is successful when it is accomplished in the agreed cost, time fame and standard quality [1]. The definition of cost overrun according to [2] is "project is not successfully completed in the approved cost" [3]. Cost overrun is a serious issue for both developed and developing countries like Pakistan. Pakistan construction industry is facing this issue for many decades and many projects are facing cost overrun exceeding beyond $100 \%$ of the initial cost [4]. According to
[5], cost overrun has a draining effect on project parties including client, contractor and consultant. Cost overrun creates issues related to litigation, cash flow, mistrust and arbitration in construction projects. According to [6], the construction projects do not perform as estimated in terms of costs. They reported that almost 9 out of 10 construction projects fall victim to significant cost overrun. The current literature review was conducted to find out studies supporting the impact of cost overrun on construction projects. Not a single study has been carried to identify the mitigation measures of cost overrun in construction of highway projects in state of Sindh, Pakistan. The main aim of this research is to find out the significant mitigation measures for causative and critical factors of cost overrun in highway projects of Pakistan particularly in the province of Sindh.

\section{LITERATURE REVIEW}

\section{A. Cost Overrun}

Many studies have been conducted on the identification of factors of project cost overrun. By carrying a survey approach, authors in [7] found the significant factors for cost overrun in Indian construction projects. Findings of their survey show that top significant factors of cost overrun in construction projects are high charges of transportation, change in materials specifications, escalation of materials price, lack of communication in the design phase, rework and changes in money exchange rates. Authors in [8] identified the causes of cost overrun were bad weather impact, inflation, schedule delay and change in scope, the pressure of local government, strikes and technical faults. Another survey was conducted among construction stakeholders in construction projects of Pakistan [9]. Results showed that significant factors which cause cost 
overrun were the unavailability of suitable contractors, the location of a project, security issues, low productivity and inaccurate project estimation. Factors causing cost overrun in construction projects of Bahrain were studied in [10]. A questionnaire was developed and dispersed among 103 expert engineers. The survey outcomes showed that major factors of cost overrun were construction mistakes, many design changes, schedule delay, poor supervision, poor site management, inaccurate time and cost estimates, delay in preparation, approval of design and drawings at the time of tender. Another study was carried out by conducting a questionnaire survey on 150 construction industry experts in Afghanistan [11]. The results of the survey identified the top ten significant factors of cost overrun namely market inflation, corruption in projects, shortage of materials, fluctuation in price of selected materials, delay in work by subcontractors, lack of project coordination, unavailability of skilled labor, changes in drawing during construction, labor disputes and inadequate number of workers. Authors in [12] recognized the major factors which caused cost overrun in construction projects were changes in material specifications by clients, changes in design during construction, delay payment progress, change in the material prices, rework due to contractor mistakes.

\section{B. Mitigation Measures}

A research was carried out to identify mitigation measures of cost overrun factors in Malaysian construction industry [13]. Mitigation measures for cost overrun factors were: strategic planning of project (project management related factor), proper planning should be adopted (design and documentation related factor), appointment of experienced sub-contractors (contractor's site management), development of human resources in the construction industry (labor related factor), regular coordination between parties (communication related factor). In [14] mitigation measures of cost overrun for small contractors were identified by conducting semi-structured interviews. Study findings were: proper supervision and management, appointment of experienced sub-contractors, use of proper method of construction, coordination between parties, and clear communication between parties.

\section{RESEARCH OBJECTIVES}

The objectives of this research are:

- To find out the most critical and causative factors which lead to cost overrun in highway/road projects.

- To determine the possible mitigation measures of identified critical factors of cost overrun.

- To find out significant mitigation measures.

\section{RESEARCH METHODOLOGY}

To attain the main objectives of this study, this research is divided into two stages. In the first stage, literature review helped us find the 64 most common factors of cost overrun. Based on the identified factors a questionnaire was developed and distributed among 30 experts of highway projects to identify the most critical factors. After analysis of survey data, a total of 8 critical factors were identified out of the initial 64 . A semi-structured questionnaire was designed on the basis of the 8 found critical factors and was distributed among the same 30 experts for determination of possible mitigation measures for the identified factors. In the second stage, a structured questionnaire was designed on the findings of the preliminary survey. The survey consisted of two parts. Part A included general information of the respondents while part B included the mitigation measures for cost overrun factors in highway projects. A five-point Likert scale was used for the determination of significance level for mitigation measures of each critical factor of cost overrun. The values of Likert scale varied from 1 for "not important" to 5 for "extremely important". The questionnaire was distributed among 350 respondents of highway projects of Sindh region (Table I). Respondents were asked to rank each mitigation measure of critical factor of cost overrun. As shown in Figure 2, 281 questionnaires were received back in a 3 month time period. 22 questionnaires were received with incomplete data and were rejected. A total of 259 valid questionnaires were analyzed. The total valid response was $74 \%$.

TABLE I. SUMMARY OF QUESTIONNAIRE DISTRIBUTION

\begin{tabular}{|c|c|}
\hline Type of organization & Distributed questionnaires \\
\hline Client & 61 \\
\hline Consultant & 101 \\
\hline Contractors & 188 \\
\hline Total & 350 \\
\hline
\end{tabular}

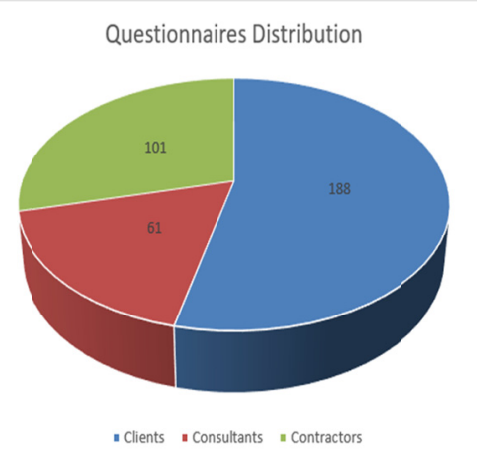

Fig. 1. Summary of questionnaire distribution

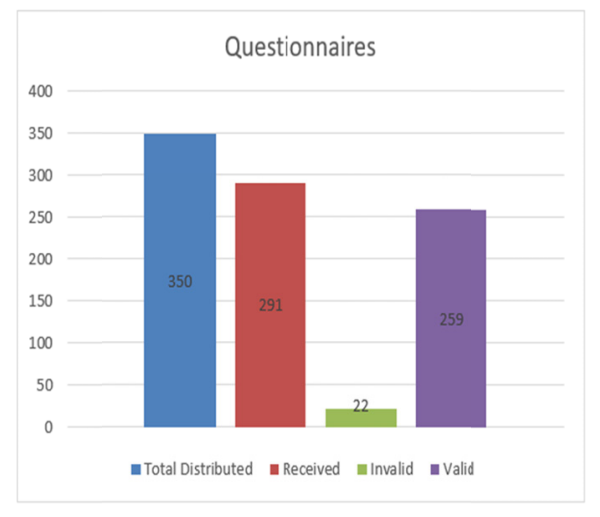

Fig. 2. Status summary of distributed questionnaires 


\section{RELIABILITY TEST}

The reliability test was carried out to check consistency and stability of collected data. It was conducted by Cronbach's alpha method, which is mostly used by researchers. The reliability of data is considered low when the value of Cronbach's alpha is less than 0.3 which means data is not acceptable and if the value of Cronbach's alpha is more than 0.7 then the data would be considered acceptable and reliable [15]. In this study, SPSS V22 was used to calculate the value of Cronbach's alpha, which gave a result of 0.837 . This indicated that the collected data is reliable and acceptable.

\section{RESULTS AND DISCUSSION}

In the first survey, total 8 critical factors for cost overrun were identified and 43 possible mitigation measures were determined. There were several mitigation measures found to control each critical factor. However, the level of effectiveness for each critical factor was different. In the final survey, the findings of the significant mitigation measures of critical factors for cost overrun are shown in Table II. These measures are listed in ascending order according to their calculated mean values. In Table III the most significant mitigation measures are listed. These measures with highest mean value were selected as significant mitigation measures for each critical factor of cost overrun.

TABLE II. MITIGATION MEASURES OF CRITICAL FACTORS OF COST OVERRUN

\begin{tabular}{|c|c|c|c|c|c|}
\hline $\begin{array}{l}\text { Critical } \\
\text { Factor }\end{array}$ & Mitigation measures & $\begin{array}{l}\text { Mean } \\
\text { Value }\end{array}$ & $\begin{array}{l}\text { Critical } \\
\text { Factor }\end{array}$ & Mitigation measures & $\begin{array}{l}\text { Mean } \\
\text { Value }\end{array}$ \\
\hline \multirow{6}{*}{ 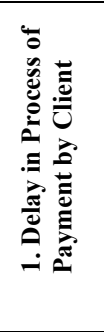 } & 1. Sufficient funds for project should be allocated. & 4.529 & \multirow{6}{*}{ 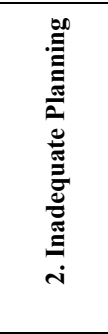 } & $\begin{array}{l}\begin{array}{l}\text { 1. Client should make strategic planning before starting } \\
\text { of project. }\end{array} \\
\end{array}$ & 4.666 \\
\hline & $\begin{array}{l}\text { 2. Many changes in regulatory authority should be } \\
\text { avoided. }\end{array}$ & 4.000 & & $\begin{array}{l}\text { 2. The planning committee should visit project site } \\
\text { before tendering. }\end{array}$ & 4.475 \\
\hline & 3. Forex restrict ration should be avoided. & 3.529 & & 3. Competent staff should be appointed by the client. & 3.936 \\
\hline & $\begin{array}{l}\text { 4. Client should stop influencing the projects } \\
\text { politically. }\end{array}$ & 3.508 & & 4. Cost of project should be estimated properly. & 3.818 \\
\hline & \multirow{2}{*}{$\begin{array}{l}\text { 5. Payment to contractor should be expedited by } \\
\text { client }\end{array}$} & \multirow[b]{2}{*}{3.372} & & 5.Effective planning should be adopted for project. & 3.598 \\
\hline & & & & $\begin{array}{l}\text { 6. The time duration of the project should be estimated } \\
\text { properly. }\end{array}$ & 3.460 \\
\hline \multirow{5}{*}{ 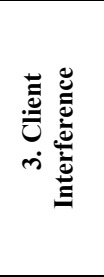 } & $\begin{array}{l}\text { 1.Favoured contractor should not be appointed by } \\
\text { client. }\end{array}$ & 4.691 & \multirow{5}{*}{ 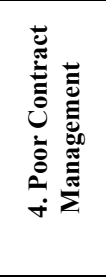 } & 1. Contracts should be awarded on merit basis & 4.607 \\
\hline & 2. Approvals of work should be on time. & 4.431 & & 2. Contract document should be clear to understand. & 4.176 \\
\hline & $\begin{array}{l}\text { 3. Transfer of key posts in project should be avoided } \\
\text { in top management. }\end{array}$ & 4.004 & & $\begin{array}{l}\text { 3. Well reputed and well-experienced consultant should } \\
\text { be hired for the project. }\end{array}$ & 3.558 \\
\hline & 4. Political influence should be avoided by client. & 3.717 & & 4.Contract documents should be well detailed. & 3.333 \\
\hline & $\begin{array}{l}\text { 5.Policies of project should not be revised on basis of } \\
\text { favouritism. }\end{array}$ & 3.686 & & $\begin{array}{l}\text { 5. Experienced staff should be employed for making } \\
\text { comprehensive contract document }\end{array}$ & 3.201 \\
\hline \multirow{5}{*}{ 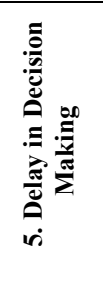 } & 1. Proper decisions should be made on time. & 4.356 & \multirow{5}{*}{ 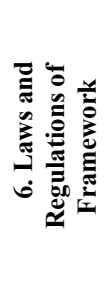 } & $\begin{array}{l}\text { 1.General policies for all project should be adopted by } \\
\text { client. }\end{array}$ & 4.779 \\
\hline & $\begin{array}{l}\text { 2. The competent and qualified team should be } \\
\text { employed. }\end{array}$ & 4.225 & & $\begin{array}{l}\text { 2. Laws and regulations should be clear so that } \\
\text { contractor can understand easily. }\end{array}$ & 4.117 \\
\hline & 3. Favouritism and nepotism should be avoided. & 3.862 & & $\begin{array}{l}\text { 3. Laws, regulations, and policies should be revised } \\
\text { every year. }\end{array}$ & 3.637 \\
\hline & $\begin{array}{l}\text { 4.Communication between parties should continue to } \\
\text { take proper decisions. }\end{array}$ & 3.759 & & 4. Law and regulations of different departments also be & 3.411 \\
\hline & 5. Client should arrange frequent meetings. & 3.593 & & & \\
\hline \multirow{5}{*}{ 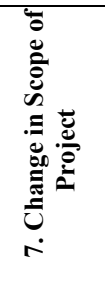 } & $\begin{array}{l}\text { 1. Proper assessment of construction site should be } \\
\text { done. }\end{array}$ & 4.150 & \multirow{5}{*}{ 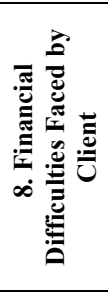 } & $\begin{array}{l}\text { 1. Adequate funds should be kept for each running } \\
\text { project. }\end{array}$ & 4.740 \\
\hline & $\begin{array}{l}\text { 2. Climatic conditions and environmental impacts of } \\
\text { the site should be foreseen. }\end{array}$ & 4.004 & & $\begin{array}{l}2 \text { The donor should start a project on the availability of } \\
\text { funds. }\end{array}$ & 4.529 \\
\hline & $\begin{array}{l}\text { 3. Accessibility of different resources should be } \\
\text { inspected. }\end{array}$ & 3.710 & & 3. Funds should not be transferred to any other project. & 4.009 \\
\hline & \multirow[b]{2}{*}{ 4. Political influence should be avoided } & \multirow[b]{2}{*}{3.558} & & 4. Finance should allocate funds on time to the client. & 3.764 \\
\hline & & & & $\begin{array}{l}\text { 5. The client should release funds to contractors as per } \\
\text { work was done at the site. }\end{array}$ & 3.436 \\
\hline
\end{tabular}

\section{A. Delay in Process of Payment by Owner}

The factor named "delay in process of payment by the owner" had five possible mitigation measures suggested by experts. Among these five mitigation measures, the "sufficient allocation of each project" was found significant having maximum mean value of 4.53 Contractor plays an important role in the completion of the project but unfortunately contractors always faces the problem of payment from the client. Many projects have suffered from cost overrun due to delay in process of payment by the client [16].

\section{B. Poor Planning}

The second factor "poor planning" had six possible mitigation measures suggested by experienced respondents. "client should make strategic planning before starting of project" is ranked as most significant with mean value of 4.67 . 
Adequate planning is necessary for each project but unfortunately many projects have faced the problem of cost overrun due to inadequate planning in project by client [17].

TABLE III. SIGNIFICANT MITIGATION MEASURES FOR CRITICAL FACTORS OF COST OVERRUN

\begin{tabular}{|c|c|c|}
\hline S. No. & Critical Factor & Significant Mitigation Measures \\
\hline 01 & $\begin{array}{l}\text { Delay in process of } \\
\text { payment by owner }\end{array}$ & $\begin{array}{l}\text { Sufficient funds for project should be } \\
\text { allocated. }\end{array}$ \\
\hline 02 & Poor planning & $\begin{array}{l}\text { Client should make strategic planning } \\
\text { before starting of project }\end{array}$ \\
\hline 03 & Owner interference & $\begin{array}{l}\text { Favoured contractor should not be } \\
\text { appointed by client. }\end{array}$ \\
\hline 04 & $\begin{array}{l}\text { Inadequate contract } \\
\text { management }\end{array}$ & $\begin{array}{l}\text { Contracts should be awarded on merit } \\
\text { basis }\end{array}$ \\
\hline 05 & Delay in decisions & $\begin{array}{c}\text { Proper decisions should be made on } \\
\text { time }\end{array}$ \\
\hline 06 & $\begin{array}{l}\text { Regulations of } \\
\text { framework }\end{array}$ & Laws and regulations of framework \\
\hline 07 & $\begin{array}{l}\text { Sudden changes in } \\
\text { project scope }\end{array}$ & $\begin{array}{l}\text { Proper assessment of construction site } \\
\text { should be done }\end{array}$ \\
\hline 08 & $\begin{array}{l}\text { Financial issues } \\
\text { faced by client }\end{array}$ & $\begin{array}{l}\text { Adequate funds should be kept for } \\
\text { each running project }\end{array}$ \\
\hline
\end{tabular}

\section{Owner Interference}

Five possible mitigation measures were recommended by experts for this factor of cost overrun. From these five measures "favored contractor should not be appointed by client" was observed as the most significant measure with mean value of 4.96. Client interference which includes appointment of favored contractor, change in administrative posts, or changes in design on favoritism basis, leads to cost overrun in projects [18].

\section{Inadequate Contract Management}

For this factor highway experts advised five controlling measures. "Contracts should be awarded on merit basis" mitigation measure was found most significant with mean value of 4.61. Contract document should be clear to all stakeholders of the project and easy to understand. It has been observed that projects faced cost overrun because of poor contract management [19].

\section{E. Delay in Descisions}

Five mitigation measures were proposed by highway experts for this factor of cost overrun. Among these "proper decisions should be made on time" had mean value of 4.36 and was identified as the significant one. Most of the decisions are taken by client and consultants and delay may result in suspension of construction activities. Delay in taking decisions may cause cost overrun in construction projects [20].

\section{F. Regulations of Framework}

Four mitigation measures were advised by highway experts for this factor. "General policies on all projects should be adopted by the client" was the most significant measure with mean value of 4.78. Unclear policies, laws and regulations related to project may arise disputes during execution process, which could be another cause of cost overrun in construction projects [21].

\section{G. Sudden Changes in Project Scope}

Four potential mitigation measures were suggested by highly experienced respondents for this factor of cost overrun. Out of four mitigation measures, "proper assessment of construction site should be done" was found most significant with mean value of 4.15. Change in scope refers to bringing in activities during execution of the project which were never planned. This is commonly due to sudden demands from the client side. Changes in the form of reduction, addition or modification, can consequentially effect on the overall cost of the project. Changes in scope can influence the prime cost of materials and also lead the project in cost overrun [22].

\section{H. Financial Issues Faced by Client}

Experts of highway recommended five possible controlling measures for this factor. After analysis "adequate funds should be kept for each running project" was identified as the most significant mitigation measure with mean value of 4.74. Availability of funds should be managed by client for each project. Unfortunately, it has been observed that, in many construction projects the client has insufficient financial support which causes cost overrun in the project [23].

\section{CONCLUSION}

In this research, an attempt was made to identify critical factors of cost overrun in highway projects in Pakistan, particularly in Sindh province. The study also helped in the determination of significant mitigation measures for these identified factors. Based on the results of this research, the following recommendations are made to mitigate the critical factors of cost overrun in highway projects.

1. Sufficient funds for the project should be allocated for successful completion of the project.

2. The client should make a strategic plan before initiating any highway project.

3. Political influence should be avoided by the client in appointment of a contractor.

4. Contract document should be clear enough to be understood by all parties involved.

5. Communication between parties should be continuous.

6. General policies on all projects should be adopted by client.

7. Proper assessment of construction site should be done by the client.

8. Adequate funds should be kept for each running project.

\section{REFERENCES}

[1] N. Ejaz, I. Ali, M. F. Tahir, "Assessment of delays and cost overruns during construction projects in Pakistan", available at: http://dl.lib.mrt.ac.lk/handle/123/9431, 2013

[2] I. Avotos, "Cost-relevance analysis for overrun control", International Journal of Project Management, Vol. 1, No. 3, pp. 142-148, 1983

[3] N. Azhar, R. U. Farooqui, S. M. Ahmed, "Cost overrun factors in construction industry of Pakistan", First International Conference on Construction In Developing Countries, Advancing and Integrating 
Construction Education, Research \& Practice, Karachi,, Pakistan, pp. 499-508, August 4-5, 2008

[4] I. Abdul Rahman, A. H. Memon, A. Azis, A. Asmi, N. H. Abdullah, "Modeling causes of cost overrun in large construction projects with partial least square-SEM approach: contractor's perspective", Research Journal of Applied Sciences, Engineering and Technology, Vol. 5, No. 6, pp. 1963-1972, 2013

[5] A. Alhomidan, "Factors affecting cost overrun in road construction projects in Saudi Arabia", International Journal of Civil \& Environmental Engineering, Vol. 13, No. 03, 2013

[6] A. C. Devi, K. Ananthanarayanan, "Factors influencing cost over-run in Indian construction projects," MATEC Web of Conferences, Vol. 120, p. 02023,2017

[7] S. Shanmugapriya, K. Subramanian, "Investigation of significant factors influencing time and cost overruns in Indian construction projects", International Journal of Emerging Technology and Advanced Engineering, Vol. 3, No. 10, pp. 734-740, 2013

[8] C. Kaliba, M. Muya, K. Mumba, "Cost escalation and schedule delays in road construction projects in Zambia", International Journal of Project Management, Vol. 27, No. 5, pp. 522-531, 2009

[9] I. Zafar, T. Yousaf, S. Ahmed, "Evaluation of risk factors causing cost overrun in road projects in terrorism affected areas Pakistan-a case study", KSCE Journal of Civil Engineering, Vol. 20, No. 5, pp. 1613 1620,2016

[10] H. A. M. Abusafiya, S. M. A. Suliman, "Causes and Effects of Cost Overrun on Construction Project in Bahrain: Part I (Ranking of Cost Overrun Factors and Risk Mapping)", Modern Applied Science, Vol. 11, No. 7, pp. 20-27, 2017

[11] S. Ahady, S. Gupta, R. K. Malik "“A study of the causes of cost overrun in construction industry in Afghanistan", International Journal of Engineering Development and Research, Vol. 5, No. 3, pp. 978-985, 2017

[12] P. Jadhav, D. Desai, A. Gupta, “Analysis of Construction Cost Overrun Causes-Contractor's View", Imperial Journal of Interdisciplinary Research, Vol. 2, No. 8, pp. 908-910, 2016

[13] A. A. Ade, H. M. Aftab, A. Ismail, T. A. Ahmad, "Controlling cost overrun factors in construction projects in Malaysia", Journal of Applied Science, Engineering and Technology, Vol. 5, No. 8, pp. 2621-2629, 2013

[14] J. A. B. Awolesi, J. K. Fabi, O. A. Akinseinde, "Assessment of Contractors' Mitigating Measures for Cost Overrun of Building Projects in South-Western Nigeria”, Journal of Sustainable Development, Vol. 8, No. 9, pp. 139-146, 2015

[15] L. Xin, W. Rong, "Survey research on relationship among service failure, service recovery and customer satisfaction", International Conference on Management Science and Engineering, Harbin, China, pp. 1121-1126, August 20-22, 2007

[16] S. Sohu, A. H. Abdullah, S. Nagapan, A. Fattah, K. Ullah, K. Kumar "Contractors perspective for critical factors of cost overrun in highway projects of Sindh, Pakistan", AIP Conference Proceedings, Vol. 1892, No. 1, p. 080002, 2017

[17] A. Senouci, A. A. Ismail, N. Eldin, "Time and Cost Overrun in Public Construction Projects in Qatar Procedia Engineering, Vol. 164, pp. 368375,2016

[18] I. Ismail, "Risk assessment of time and cost overrun factors throughout construction project lifecycle", PhD Thesis, Universiti Tun Hussein Onn Malaysia, 2014

[19] Z. Shehu, I. R. Endut, A. Akintoye, "Factors contributing to project time and hence cost overrun in the Malaysian construction industry", Journal of Financial Management of Property and Construction, Vol. 19, No. 1, pp. 55-75, 2014

[20] A. Ambituuni, "Five causes of Project delay and cost overrun, and their mitigation measures", MSc Thesis, The Robert Gordon University, 2011

[21] J. K. Larsen, G. Q. Shen, S. M. Lindhard, T. D. Brunoe, "Factors affecting schedule delay, cost overrun, and quality level in public construction projects", Journal of Management in Engineering, Vol. 32, No. 1, p. 04015032, 2015
[22] R. O. Asiedu, E. Adaku, D. G. Owusu-Manu, "Beyond the causesrethinking mitigating measures to avert cost and time overruns in construction projects", Construction Innovation, Vol. 17, No. 3, pp. 363380, 2017

[23] A. H. Memon, I. A. Rahman, M. R. Abdullah, A. A. A. Azis, "Factors affecting construction cost performance in project management projects: Case of MARA large projects", International Journal of Civil Engineering and Built Environment, Vol. 1, No. 1, pp. 30-35, 2014 